\title{
PENGEMBANGAN MODEL PEMBELAJARAN TERINTEGRASI SOFT SKILL DAN HARD SKILL DALAM MENINGKATKAN KOMPETENSI WARGA BELAJAR PADA LEMBAGA KURSUS KECANTIKAN
}

\author{
Wiwin Herwina, H. Ajid Madjid, \& H.adang Daniel \\ e-mail: Ikp.yuwita@yahoo.co.id \\ Fakultas Keguruan dan IImu Pendidikan, Universitas Siliwangi
}

\begin{abstract}
Abstrak: Penelitian ini dilatarbelakangi oleh permasalahan bagaimana kondisi awal pembelajaran pada lembaga kursus kecantikan, model konseptual pembelajaran terintegrasi soft skill dan hard skill, implementasi model pembelajaran terintegrasi soft skill dan hard skill, serta efektivitas model pembelajaran terintegrasi soft skill dan hard skill yang dalam meningkatkan kompetensi warga belajar. Penelitian ini bertujuan untuk menemukan model pembelajaran terintegrasi soft skill dan hard skill dalam meningkatkan kompetensi warga belajar yang dilaksanakan di LKP Yuwita Kota Tasikmalaya pada tahun 2017. Metode penelitian yang digunakan adalah metode deskripsi dan eksperimen. Sampel dalam penelitian terdiri dari satu orang pengelola, dua orang instruktur, dan 20 orang warga belajar. Hasil penelitian menunjukkan (1) kondisi awal pembelajaran pada lembaga kursus kecantikan, masih didominasi oleh tutor, (2) validasi ahli telah menghasilkan model pembelajaran terintegrasi dalam meningkatkan kompetensi warga belajar, (3) implementasi model dapat menghasilkan model pembelajaran terintegrasi soft skill dan hard skill untuk meningkatkan kompetensi warga belajar, dan (4) model pembelajaran terintegrasi soft skill dan hard skill yang dikembangkan dalam penelitian ini sesuai dengan hasil analisis kualitatif maupun kuantitatif dari hasil pengujian telah efektif meningkatkan kompetensi warga belajar pada lembaga kursus kecantikan. Penelitian ini menyimpulkan bahwa model pembelajaran terintegrasi soft skill dan hard skill yang dikembangkan ternyata telah efektif dalam meningkatkan kompetensi warga belajar pada lembaga kursus kecantikan.
\end{abstract}

Kata-kata kunci: model terintegrasi, soft skill, hard skill, kompetensi

\section{DEVELOPMENT OF INTEGRATED LEARNING MODELS SOFT SKILL AND HARD SKILL INCREASE THE COMPETENCY OF BEAUTY COURSE INSTITUTIONS}

\begin{abstract}
The research is based on the problem of how the initial condition of learning in the beauty course Institute, how the conceptual model of integrated learning soft skill and hard skills, how the implementation of integrated learning models soft skill and hard skill, how the effectiveness of the integrated learning model soft skill and hard skill that can improve the competence residents learn. The purpose of research to find the learning model integrated soft skill and hard skill in improving competence of studying citizen who conducted at LKP Yuwita city of Tasikmalaya in 2017. Research method used is description and experiment method. The sample for this research consists of one-person manager, two-person instructor, 20 people studying citizen. The results from the study showed (1) the initial condition of learning in the beauty course Institute, still dominated by the tutor. The residents were less involved in the learning, (2) expert validation has resulted in the integrated learning model in improving the competence of studying citizens, (3) learning of integrated soft skill and hard skill to improve the competence of studying citizens, and (4) integrated learning model of soft skill and hard skill developed for this research according to the result of qualitative and quantitative analysis from the test results has effectively increased the competence of studying citizen at the beauty course Institute. The conclusion from this research is that the integrated learning model of soft skill and hard skill developed has been effective in improving the competence of studying citizens at the beauty course Institute.
\end{abstract}

Keywords: integrated model, soft skill, hard skills, competence 


\section{PENDAHULUAN}

Pendidikan merupakan upaya terencana dan berkesinambungan yang dilakukan untuk mengembangkan kemampuan manusia agar menjadi manusia yang berkualitas. Proses pendidikan yang dilakukan secara terencana dan berkesinambungan oleh lembaga pendidikan menghasilkan berbagai lulusan untuk setiap jenjangnya. Sesuai dengan tujuan pendidikan tersebut, maka lulusan yang dihasilkan harus berkualitas atau bermutu. Tuntutan akan lulusan lembaga pendidikan yang bermutu sangat diperlukan dewasa ini karena semakin ketatnya persaingan dalam lapangan kerja. Mengantisipasi perubahan-perubahan yang begitu cepat serta tantangan yang semakin besar dan kompleks, penting bagi lembaga pendidikan untuk mengupayakan segala cara dalam meningkatkan daya saing lulusan serta produk-produk akademik lainnya, salah satunya dapat dicapai melalui perbaikan sistem pendidikan. Upaya ini diharapkan dapat melahirkan manusia-manusia yang berkualitas sebagai bagian dari suatu masyarakat yang terus belajar (learning society). Hal ini sejalan dengan pendapat Anwar (2004) bahwa "Memasuki era globalisasi di abad ke-21 diperlukan suatu paradigma baru dalam sistem pendidikan dunia, dalam rangka mencerdaskan umat manusia dan memelihara persaudaraan".

Menurut Delor (1996) dalam Anwar (2004), pemikiran mengenai paradigma sistem pendidikan tersebut telah disadari oleh UNESCO yang merekomendasikan "empat pilar pembelajaran" untuk memasuki era globalisasi, yaitu program pembelajaran yang diberikan hendaknya mampu memberikan kesadaran kepada masyarakat sehingga mau dan mampu belajar. Bahan belajar yang dipilih hendaknya mampu memberikan suatu pekerjaan alternatif kepada warga belajarnya, dan mampu memberikan motivasi untuk hidup dalam era sekarang dan memiliki orientasi hidup ke masa depan. Pembelajaran tidak cukup hanya diberikan dalam bentuk keterampilan untuk dirinya sendiri, tetapi juga keterampilan untuk hidup bertetangga, bermasyarakat, berbangsa dan hidup dalam pergaulan antar bangsa-bangsa dengan semangat kesamaan dan kesejajaran.

Keempat pilar yang dikemukakan UNESCO tidak bisa dilihat sebagai suatu yang berdiri sendiri, melainkan keempatnya merupakan suatu garis kontinum dalam proses pencapaiannya karena keempat pilar ini harus menjadi acuan bagi lembagalembaga pendidikan dalam melaksanakan fungsinya. Salah satu lembaga pendidikan yang memiliki perhatian penuh terhadap pengembangan manusia atau lulusan yang berkualitas adalah pendidikan luar sekolah. Trisnamansyah S dalam Kamil (2010) menyatakan bahwa ilmu pendidikan luar sekolah diartikan sebagai ilmu yang secara sistematik mempelajari interaksi sosial-budaya antara warga belajar sebagai objek dengan sumber belajar dalam rangka mencapai tujuan-tujuan pendidikan yang diinginkan, dengan menekankan pada pembentukan kemandirian, dalam rangka belajar sepanjang hayat.

Sementara itu, Combs dalam Joesoef (1986) menyatakan bahwa "Pendidikan luar sekolah adalah setiap kegiatan pendidikan yang terorganisir yang diselenggarakan di luar sistem formal, baik tersendiri maupun merupakan bagian dari suatu kegiatan yang luas yang dimaksudkan untuk memberikan layanan kepada sasaran didik tertentu dalam rangka mencapai tujuan belajar". Definisi ini menjelaskan bahwa pendidikan nonformal atau pendidikan luar sekolah merupakan kegiatan yang dilaksanakan di luar sistem pendidikan formal yang memberikan layanan kepada warga belajar untuk mencapai tujuan belajar.

Terdapat empat hal yang menjadi pilar pengembangan pendidikan luar sekolah sebagaimana dikemukakan oleh Sihombing (2000), yaitu (1) memperluas pelayanan kesempatan memperoleh pendidikan bagi masyarakat yang tidak dibelajarkan pada jalur pendidikan sekolah; (2) meningkatkan relevansi, keterkaitan dan kesepadanan programprogram pendidikan luar sekolah dengan kebutuhan masyarakat, kebutuhan pembangunan, kebutuhan dunia kerja, pengembangan industri dan ekonomi masyarakat dan pengembangan sumber daya alam; (3) peningkatan mutu penyelengggaraan dan hasil pendidikan luar sekolah; serta (4) meningkatkan efisiensi dan efektivitas penyelenggaraan pendidikan luar sekolah.

Empat pilar tersebut, bila dicermati sebenarnya mengandung arti bahwa pendidikan luar sekolah turut mengemban upaya pemerintah dalam menuntaskan masalah pembangunan 
pendidikan dewasa ini berkenaan dengan mutu, pemerataan, relevansi, efektivitas dan efisiensi. Untuk menyikapi masalah pendidikan yang dihadapi, pendidikan luar sekolah menyelenggarakan berbagai program seperti (1) Program Pendidikan Anak Usia Dini (PAUD), (2) Program Keaksaraan Fungsional, (3) Program Pendidikan Dasar, (4) Program Pendidikan Kewanitaan, (5) Program Pendidikan Luar Sekolah yang diselenggarakan oleh masyarakat (DIKLUSEMAS), dan (6) Program PLS lainnya seperti Program Pendidikan dan Pembelajaran, Program Magang, serta Pendidikan Kecakapan Hidup (LifeSkills). Program-program pendidikan luar sekolah merupakan program yang dapat dilaksanakan antar lintas sektor, oleh karena itu, program-program ini dapat dilakukan oleh siapa saja dan lembaga mana saja sepanjang para stakeholder dimaksud mempunyai niat yang tulus dan ikhlas untuk membantu upaya pendidikan secara merata, berkualitas dan berkesinambungan. Untuk merealisasikan maksud tersebut, lembaga kursus kecantikan menyelenggarakan kegiatan pembelajaran bagi warga belajar. Pembelajaran merupakan suatu kegiatan yang tersusun atas tiga bagian yaitu proses, belajar dan mengajar. Ketiga bagian tersebut memiliki makna yang berbeda.

Proses merupakan suatu rangkaian kejadian atau peristiwa dalam suatu kegiatan, selain itu dapat juga diartikan sebagai rangkaian interaksi semua unsur yang terdapat di dalam belajar mengajar, yang satu sama lain berhubungan untuk mencapai tujuan belajar. Belajar adalah proses perubahan tingkah laku yang dinyatakan dalam bentuk penguasaan, penggunaan, dan penilaian terhadap atau mengenai sikap dan nilai-nilai, pengetahuan dan kecakapan dasar yang terdapat dalam berbagai bidang studi (Rusyan, dkk, 1994). Belajar menurut Hapin dalam Syah (1995) adalah perolehan perubahan tingkah laku yang relatif menetap sebagai akibat latihan dan pengalaman, sementara itu pengertian belajar menurut Sudjana (1987) adalah proses berubahnya tingkah laku warga belajar melalui berbagai pengalaman yang diperolehnya. Belajar sebagai suatu proses tidak dapat dipisahkan dari kegiatan mengajar. Mengajar adalah usaha pemberian bimbingan kepada warga belajar untuk belajar (Hamalik 1986). Pendapat Hamalik sejalan dengan pandangan Burthon dalam Rusyan, dkk, (1994) yang menyatakan bahwa mengajar adalah upaya dalam memberikan perangsang (stimulus), bimbingan, pengarahan, dan dorongan kepada warga belajar agar terjadi proses belajar.

Tutor sangat berperan sebagai salah satu komponen yang penting dalam sistem pendidikan. Tutor adalah tutor pribadi, tenaga pengajar ekstra atau memberi les/pengajaran tambahan. Tutor merupakan sebutan bagi orang yang mengajar dalam pendidikan nonformal walaupun melakukan pembelajaran dalam pendidikan formal. Tutor adalah warga masyarakat yang mempunyai kelebihan (keahlian, kecakapan, dan kemampuan) di bidang pengetahuan dan keterampilan, khususnya di bidang mengajar dan mengelola mata pencaharian, serta memiliki semangat pengabdian yang tinggi dalam membimbing warga belajar dalam kelompok belajar untuk meningkatkan pengetahuan keterampilan sesamanya.

Terdapat beberapa kendala dalam peningkatan mutu pembelajaran pendidikan kesetaraan, yaitu (1) sulit mendapatkan tutor yang memiliki latar belakang ketutoran; (2) honorarium yang diterima tutor tidak memadai; dan (3) usaha peningkatan kemampuan tutor tidak merata, banyak tutor yang tidak pernah ditatar dan tempat tinggal tutor jauh dari warga belajar. Untuk memperoleh hasil yang baik dalam proses pembelajaran, seorang tutor hendaknya mampu melaksanakan tugasnya dengan baik dan seharusnya dilengkapi dengan kebiasaan seperti (1) kemampuan mengidentifikasi kebutuhan belajar, (2) kemampuan menyusun program pembelajaran yang berorientasi pada tujuan yang diinginkan warga belajar, (3) kemampuan berkomunikasi agar mampu menggunakan berbagai cara alam pembelajaran, (4) kemampuan menjalankan program dalam arti kemampuan mengorganisir program, (5) kemampuan menilai hasil program, dan (6) kemampuan menggunakan hasil penilaian dalam usaha memperbaiki program di masa mendatang. Oleh karena itu, tutor harus mengalami standar yang harus dicapai pada setiap kurun waktu,

Harapan setiap tutor adalah dalam proses belajar mengajar adalah warga belajar dapat mencapai hasil belajar yang sebaik-baiknya. Namun kenyataannya tidak selalu menunjukkan apa yang diharapkan itu. Banyak warga belajar yang menunjukkan tidak dapat mencapai hasil belajar sebagaimana yang diharapkan. Dalam kegiatan belajar, tutor sering menghadapi warga belajar yang mendapatkan permasalahan dalam belajar, seperti terjadinya komunikasi satu arah, sehingga warga 
belajar cenderung pasif (hanya mengikuti ceramah tutor), serta menimbulkan rasa jenuh pada diri warga belajar dalam mengikuti pembelajaran, hal ini tak ubahnya dengan kegiatan belajar mengajar yang meliputi datang, duduk mengikuti ceramah tutor, melihat tutor menulis di papan tulis, mendengarkan, lalu mengingat atau mengkopi apa adanya informasi yang disampaikan tutor.

Permasalahan lain yang ditemukan dalam pembelajaran adalah perubahan sikap serta perilaku yang diakibatkan oleh perkembangan ilmu pengetahuan dan teknologi. Djahiri (2008) dalam Trisnahada (2011) menyatakan bahwa perkembangan ilmu pengetahuan dan teknologi yang memungkinkan penyebaran informasi secara menyeluruh dapat memberikan pengaruh besar terhadap perubahan sikap serta perilaku yang akan mengakibatkan terjadinya krisis erosi nilai-moralnorma dan dehumanisasi. Selanjutnya, Sanusi (1998) dalam Trisnahada (2011) menyatakan bahwa secara perlahan-lahan akan diakui bahwa peningkatan informasi yang menyeluruh dapat menimbulkan konflik yang membingungkan pada setiap individu. Tidak dapat dipungkiri bahwa semuanya itu akan menciptakan keraguan tentang dirinya, kepercayaan yang selama ini dianutnya, dan nilai-nilai yang menjadi tuntunan dalam hidupnya.

Terdapat banyak permasalahan dalam pelaksanaan pembelajaran dipengaruhi oleh berbagai faktor yang saling mempengaruhi satu sama lain (interelasi). Faktor yang banyak ini dapat dikelompokkan menjadi beberapa kelompok faktor, umumnya dapat dikelompokkan menjadi enam kelompok, yaitu (1) faktor warga belajar; (2) faktor tutor; (3) faktor interaksi tutor-warga belajar; (4) faktor warga belajar sebagai kelompok; (5) faktor lingkungan fisik; dan (6) faktor pendorong dari luar.

Menghadapi berbagai permasalahan dalam pelaksanaan pembelajaran, tutor harus menyadari bahwa pembelajaran memiliki sifat yang sangat kompleks karena melibatkan aspek pedagogis, psikologis, dan didaktis secara bersamaan. Aspek pedagogis menunjuk pada kenyataan bahwa pembelajaran berlangsung dalam suatu lingkungan pendidikan. Oleh karena itu, tutor harus mendampingi warga belajar menuju kesuksesan belajar atau penguasaan sejumlah kompetensi tertentu. Aspek psikologis menunjuk pada kenyataan bahwa warga belajar pada umumnya memiliki taraf perkembangan yang berbeda, yang menuntut materi yang berbeda pula. Selain itu, aspek psikologis menunjuk pada kenyataan bahwa proses belajar itu sendiri mengandung variasi, seperti belajar keterampilan motorik, belajar konsep, belajar sikap, dan lain sebagainya. Perbedaan itu menuntut pembelajaran yang berbeda pula, sesuai dengan jenis-jenis belajar yang sedang berlangsung. Aspek didaktis menunjuk pada pengaturan belajar warga belajar oleh tutor. Dalam hal ini, tutor harus menentukan secara tepat jenis belajar manakah yang paling berperan dalam proses pembelajaran tertentu dengan mengingat kompetensi dasar yang harus dicapai (Mulyasa, 2006).

Akhir dari proses pendidikan dan pengajaran ini adalah kemampuan warga belajar memiliki kekuatan spiritual keagamaan, pengendalian diri, kepribadian, kecerdasan, akhlak mulia, serta keterampilan yang diperlukan dirinya, masyarakat, bangsa dan negara. Hal ini berarti proses pendidikan atau pengajaran berujung kepada pembentukan sikap, pengembangan kecerdasan dan intelektual, serta pengembangan keterampilan warga belajar sesuai dengan kebutuhan. Aspek-aspek inilah arah dan tujuan pendidikan dan pengajaran yang harus diupayakan (Trisnahada, 2011). Kenyataan yang ditemukan di lapangan, praktik pendidikan dan pengajaran di lembaga kursus selama ini lebih banyak menekankan pada aspek-aspek kognitif, yang bersifat akademik, keterampilan, dan IPTEK. Padahal menekankan aspek-aspek afektif di lapangan pendidikan dan pengajaran itu jauh lebih penting.

Pembelajaran terintegrasi (integrated learning) dapat membantu menciptakan struktur kognitif yang dapat menjembatani antara pengetahuan awal warga belajar dengan pengalaman belajar yang terkait, sehingga pemahaman warga belajar menjadi terorganisasi dan mendalam, dapat memudahkan warga belajar memahami hubungan materi dari satu konteks ke konteks lain (Depdiknas, 2007). Melalui pembelajaran terpadu, warga belajar dapat memperoleh pengalaman belajar secara nyata. Warga belajar akan terlatih untuk menemukan konsep yang dipelajari secara otentik, bermakna, dan aktif. Pembelajaran terintegrasi dapat dilakukan dengan cara memadukan satu pembelajaran/mata pelajaran yang satu dengan mata pelajaran yang lain dengan tujuan memadukan dua atau tiga keterampilan. Misalnya memadukan pembelajaran keterampilan menulis dengan keterampilan mendengarkan 
atau keterampilan menulis dengan keterampilan membaca dan atau ilmu pengetahuan alam dengan ilmu pengetahuan sosial.

\section{METODE PENELITIAN}

Penelitian ini menggunakan prosedur research and development yang pokok-pokok kegiatannya diambil dari Borg dan Gall (2003). Tahapan tersebut dimodifikasi dan disederhanakan. Penelitian dan pengembangan mempunyai sepuluh langkah namun dapat disederhanakan menjadi enam tahap yang saling berkaitan, yaitu (1) studi pendahuluan yang bersifat evaluatif dan eksploratif, terhadap model pembelajaran sebelumnya; (2) penyusunan model konseptual; (3) validasi model konseptual; (4) uji coba model konseptual; (5) revisi hasil uji coba untuk mendapatkan model akhir; dan (6) penyusunan laporan penelitian.

Penelitian dan pengembangan bertujuan untuk menghasilkan model pembelajaran terpadu dan terdapat empat tahap dalam proses pelaksanaannya yaitu (1) studi pendahuluan mencakup studi literatur dan studi lapangan untuk mengetahui kondisi awal dan kebutuhan pembelajaran, (2) penyusunan model konseptual yang ditujukan untuk menghasilkan rumusan model pembelajaran yang diprediksi dapat diimplementasikan dan meningkatkan kompetensi warga, (3) uji coba model/implementasi model yang ditujukan untuk menghasilkan model pembelajaran terintegrasi soft skill dan hard skill yang akomodatif, serta (4) uji efektivitas model pembelajaran terintegrasi soft skill dan hard skill dalam meningkatkan kompetensi warga belajar pada lembaga kursus kecantikan.

Penelitian ini dilakukan di Lembaga Kursus Yuwita Kota Tasikmalaya Provinsi Jawa Barat dan diselenggarakan pada tahun 2017. Teknik pengumpulan data penelitian melalui observasi, wawancara, tes dan studi dokumentasi. Teknik analisis data yang digunakan adalah deskriptif kualitatif yang diperkuat dengan teknik analisis statistik kuantitatif melalui uji-t. Pengolahan data penelitian yang sudah diperoleh dimaksudkan sebagai suatu cara mengorganisasikan data sedemikian rupa sehingga dapat dibaca (readable) dan ditafsirkan (interpretable) serta dapat menjawab pertanyaan penelitian. Hal ini sejalan dengan pendapat Sudjana dan Ibrahim (2001) bahwa data yang diperoleh dari sampel melalui instrumen yang dipilih akan digunakan untuk menjawab pertanyaan penelitian. Oleh sebab itu, data perlu diolah dan dianalisis agar mempunyai makna guna pemecahan masalah.

Pada dasarnya kegiatan pengolahan data dan analisis data dalam penelitian ini dilakukan secara kualitatif dan kuantitatif. Pengolahan secara kualitatif dimulai sejak pengumpulan data dilakukan, namun analisis tersebut bersifat parsial, sedangkan analisis yang diharapkan adalah analisis yang bersifat konstektual. Untuk memperoleh analisis yang bersifat konstektual, maka harus dianalisis setelah semua data terkumpul secara utuh. Sehubungan dengan hal tersebut, maka langkah-langkah analisis data dalam penelitian ini adalah (1) mengumpulkan catatan-catatan lapangan yang berasal dari hasil wawancara, observasi, dan studi dokumentasi, serta triangulasi; (2) mengumpulkan data yang sejenis; (3) menyusun data sesuai dengan permasalahan dan tujuan penelitian; (4) menganalisis hubungan data yang satu dengan yang lain; (5) memberikan komentar berupa tanggapan, dan tafsiran terhadap data secara konstektual; (6) mendeskripsikan data dalam bentuk pertanyaan-pertanyaan umum, sekaligus menyusun temuan-temuan penelitian, baik yang berhubungan dengan permasalahan penelitian maupun tidak; (7) menyusun temuan yang berupa gagasan yang bersifat inovasi; dan (8) menyimpulkan laporan penelitian secara umum.

\section{HASIL DAN PEMBAHASAN}

\section{Kondisi Awal Pembelajaran pada Lembaga Kursus Kecantikan}

Hasil observasi menyatakan bahwa umumnya tutor masih menggunakan model pembelajaran konvensional serta masih menggunakan metode ceramah, yang menekankan pada materi tanpa memberikan waktu yang cukup kepada warga belajar untuk merefleksikan materi-materi yang disajikan. Pembelajaran hanya berpusat pada satu arah, interaksi yang kurang di antara warga belajar, tidak 
ada kelompok-kelompok untuk bekerja sama, hasil belajar dari warga belajar pun sesuai dengan studi dokumen skornya rata-rata menengah ke bawah.

Umumnya, model pembelajaran yang diterapkan adalah ceramah dengan kegiatan pembelajaran yang didominasi oleh tutor. Warga belajar hanya sebagai pendengar setia karena kurang diberikan peluang dalam memberikan tanggapan atau komentar. Tutor kurang melibatkan warga belajar dalam kegiatan pembelajaran, serta kurangnya kerja sama antara tutor dan warga belajar. Kondisi seperti ini kurang memberikan motivasi kepada warga belajar untuk bergiat dalam meningkatkan hasil belajarnya.

Model pembelajaran yang diterapkan di sanggar oleh para tutor dan pamong belajar belum berlandaskan konsep dan acuan yang jelas tentang model pembelajaran kolaboratif yang sesuai dengan kebutuhan nyata di lapangan sebagai kelompok sasaran program. Model pembelajaran masih bersifat monoton, berpusat pada tutor dan pamong belajar sementara warga belajar sifatnya menunggu dan mendengarkan materi yang disampaikan, mereka kurang dilibatkan dalam proses pembelajaran. Model pembelajaran seperti ini tentunya kurang memberdayakan warga belajar sehingga mereka kurang bergairah dan kurang termotivasi dalam belajar.

Model Konseptual Pembelajaran Terintegrasi Soft Skill dan Hard Skill untuk Meningkatkan Kompetensi Warga Belajar pada Lembaga Kursus Kecantikan

Istilah Pembelajaran Integratif berasal dari kata "integrated teaching and learning" atau "integrated curriculum approach". Konsep ini telah lama dikemukakan oleh John Dewey sebagai usaha untuk mengintegrasikan perkembangan dan pertumbuhan warga belajar dan kemampuan pengetahuannya. Pada perspektif bahasa, pembelajaran integratif sering diartikan sebagai pendekatan tematik (thematic approach).

Pembelajaran integratif didefinisikan sebagai proses dan strategi yang mengintegrasikan isi bahasa (membaca, menulis, berbicara, dan mendengar) dan mengkaitkannya dengan mata pelajaran lain. Konsep ini mengintegrasikan bahasa (language arts content) sebagai pusat pembelajaran yang dihubungkan dengan berbagai tema atau topik pembelajaran.

Pembelajaran integratif juga sering disebut pembelajaran koheren (a coherent curriculum approach) yang memandang bahwa pembelajaran integratif merupakan pendekatan untuk mengembangkan program pembelajaran yang menyatukan dan menghubungkan berbagai program pendidikan. Keterhubungan dalam kurikulum bukan hanya antara mata pelajaran dan kebutuhan serta minat dan bakat anak, tetapi juga menghubungkan antara tujuan dan kegiatan, serta kondisi masyarakat pada umumnya.

Definisi lain tentang pembelajaran integratif adalah pendekatan holistik yang mengkombinasikan aspek epistemologi, sosial, psikologi dan pendekatan pedagogi untuk pendidikan anak, yaitu menghubungkan antara otak dan otot, antara individu dan individu, antara individu dan komunitas, dan antara domain-domain pengetahuan (Saud, 2006).

Menurut para pakar pendidikan, pembelajaran integratif sangat tepat diterapkan pada sekolah dasar, karena pada jenjang pendidikan dasar warga belajar memahami dan menghayati pengalamannya masih secara totalitas serta masih sulit menghadapi pemilahan dan pemisahan yang artifisial.

Keintegratifan dalam pembelajaran ini dapat dilihat dari aspek proses atau waktu, aspek bahan ajar dan aspek kegiatan belajar mengajar. Model pembelajaran integratif pada dasarnya merupakan suatu sistem pembelajaran yang memungkinkan warga belajar baik secara individual maupun kelompok aktif menggali dan menemukan konsep serta prinsip-prinsip keilmuan secara holistik, bermakna dan otentik.

Pembelajaran integratif menurut Prabowo (2000) adalah suatu proses pembelajaran dengan melibatkan berbagai bidang studi. Pendekatan pembelajaran seperti ini diharapkan akan dapat memberikan pengalaman yang bermakna kepada warga belajar. Arti bermakna pada konteks pembahasan ini adalah anak diharapkan dapat memperoleh pemahaman terhadap konsepkonsep yang mereka pelajari dalam pembelajaran integratif melalui pengalaman langsung dan menghubungkannya dengan konsep lain yang sudah mereka pahami.

Dari beberapa pengertian tersebut, dapat disimpulkan bahwa model pembelajaran integratif adalah suatu sistem pembelajaran yang memadukan bebagai macam konsep pelajaran, dalam hal ini melibatkan bebagai macam bidang studi. 
Pembelajaran integratif sangat penting dalam kegiatan belajar pembelajaran, misalnya seperti kesesuaian yang merupakan dunia nyata, proses pemahaman warga belajar terhadap suatu konsep dalam suatu peristiwa atau objek lebih terorganisir, pembelajaran akan lebih bermakna, memberi peluang warga belajar untuk mengembangkan kemampuan diri, serta memperkuat kemampuan yang diperoleh dan efisien waktu.

Beberapa alasan pentingnya pembelajaran integratif adalah (1) dunia warga belajar adalah dunia nyata, tingkat perkembangan mental warga belajar selalu dimulai dengan tahap berpikir nyata, dalam kehidupan sehari-hari mereka tidak melihat mata pelajaran berdiri sendiri melainkan melihat objek atau peristiwa yang di dalamnya memuat sejumlah konsep/materi beberapa mata pelajaran; (2) proses pemahaman warga belajar terhadap suatu konsep dalam suatu peristiwa/objek lebih teroganisir, proses pemahaman warga belajar terhadap suatu konsep dalam suatu objek sangat bergantung pada pengetahuan yang sudah dimiliki warga belajar sebelumnya, masing-masing warga belajar selalu membangun sendiri pemahaman terhadap konsep baru menjadi "arsitek" pembangun gagasan baru, tutor hanya sebagai "fasilitator" atau mempermudah agar peristiwa belajar dapat terjadi, warga belajar mendapat gagasan baru jika pengetahuan yang disajikan selalu berkaitan dengan pengetahuan yang sudah dimilikinya; (3) pembelajaran akan lebih bermakna, pembelajaran akan lebih bermakna jika pelajaran yang sudah dipelajari oleh warga belajar dapat dimanfaatkan untuk mempelajari materi berikutnya, pembelajaran integratif sangat dibutuhkan untuk memanfaatkan pengetahuan sebelumnya; (4) memberi peluang warga belajar untuk mengembangkan kemampuan diri, pengajaran integratif memberi peluang warga belajar untuk mengembangkan tiga ranah sasaran pendidikan secara bersamaan yang meliputi sikap (jujur, teliti,tekun, terbuka terhadap gagasan ilmiah), keterampilan (memperoleh, memanfaatkan dan memilih informasi, menggunakan alat, bekerja sama, dan kepemimpinan), dan ranah kognitif (pengetahuan); (5) memperkuat kemampuan yang diperoleh, kemampuan yang diperoleh dari satu mata pelajaran akan saling memperkuat kemampuan yang diperoleh dari mata pelajaran lain; (6) efisiensi waktu, tutor dapat lebih menghemat waktu dalam menyusun persiapan mengajar, selain warga belajar, tutor dapat belajar lebih bermakna terhadap konsepkonsep sulit yang akan diajarkan.

Implementasi Model Pembelajaran Terintegrasi Soft Skill dan Hard Skill untuk Meningkatkan Kompetensi Warga Belajar pada Lembaga Kursus Kecantikan di Kota Tasikmalaya.

Proses pembelajaran yang dilakukan pada pengembangan model pembelajaran ini menggunakan pendekatan pembelajaran terintegrasi. Model pembelajaran integratif merupakan salah satu model implementasi kurikulum yang dapat diaplikasikan pada semua jenjang pendidikan. Model pembelajaran integratif merupakan suatu pendekatan pembelajaran yang memungkinkan warga belajar baik secara individual maupun kelompok aktif mencari, menggali, dan menemukan konsep serta prinsip secara holistik dan otentik. Melalui pembelajaran integratif, warga belajar dapat memperoleh pengalaman langsung, sehingga dapat menambah kekuatan untuk menerima, menyimpan, dan memproduksi kesan-kesan tentang hal-hal yang dipelajarinya, dengan demikian warga belajar terlatih untuk dapat menemukan sendiri berbagai konsep yang dipelajari secara holistik, bermakna, otentik, dan aktif.

Teknik pembelajaran integratif dilaksanakan dengan mengembangkan suatu topik pada suatu mata pelajaran, kemudian topik tersebut dikaitkan dengan mata pelajaran lain yang memiliki tema yang sama. Cara pengemasan pengalaman belajar yang dirancang tutor sangat berpengaruh terhadap kebermaknaan pengalaman bagi para warga belajar. Pengalaman belajar lebih menunjukkan kaitan unsur-unsur konseptual menjadikan proses pembelajaran lebih efektif. Kaitan konseptual yang dipelajari dengan sisi bidang kajian yang relevan akan membentuk skema (konsep), sehingga warga belajar akan memperoleh pengetahuan yang utuh.

Pengembangan model pembelajaran terintegrasi soft skill dan hard skill bertujuan untuk (1) mendapatkan masukan dari dunia industri berupa komponen-komponen apa yang harus ada dalam pengembangan model pembelajaran pada lembaga kursus kecantikan; (2) menghasilkan rancangan pengembangan model pembelajaran pada lembaga kursus kecantikan; (3) menghasilkan perangkat yang dibutuhkan untuk pelaksanaan model pembelajaran pada lembaga kursus kecantikan; serta (4) menghasilkan model pembelajaran pada lembaga kursus kecantikan yang efektif untuk digunakan. 
Berdasarkan hal tersebut, diperlukan kegiatan pengembangan model pembelajaran yang mengarah pada upaya perbaikan. Upaya tersebut dilakukan melalui pengembangan model pembelajaran kursus kewirausahaan, sehingga warga belajar dapat mengaplikasikan pengetahuan (knowledge), keterampilan (skill), sikap-sikap, dan perilaku bekerja (employability). Pelatihan/diklat atau kursus adalah suatu proses yang sistematis untuk mengembangkan pengetahuan dan keterampilan dari sikap yang diperlukan dalam melaksanakan tugas seseorang serta diharapkan akan dapat mempengaruhi penampilan kerja, baik oleh orang yang bersangkutan maupun organisasi tempat bekerja. Pembelajaran integratif memiliki tiga variasi pembelajaran integratif yang berkenaan dengan proses pendidikan dan pembelajaran, yaitu (1) kurikulum integratif (integrated curriculum), (2) hari integratif (integrated day), dan (3) pembelajaran integratif (integrated learning).

Model pembelajaran integratif yang mungkin dapat diadaptasi adalah (1) fragmentasi, dalam model ini suatu disiplin yang berbeda dan terpisah yang dikembangkan merupakan suatu kawasan dari suatu mata pelajaran; (2) koneksi, setiap topik ke topik, tema ke tema, atau konsep ke konsep isi mata pelajaran dihubungkan secara tegas; (3) sarang, tutor menargetkan variasi keterampilan (sosial, berpikir, dan keterampilan khusus) dari setiap mata pelajaran; (4) rangkaian/urutan, topik atau unit pembelajaran disusun dan diurutkan selaras dengan yang lain, ide yang sama diberikan dalam kegiatan yang sama sambil mengingatkan konsepkonsep yang berbeda; (5) patungan, perencanaan dan pembelajaran menyatu dalam dua disiplin yang konsep/gagasannya muncul saling mengisi sebagai suatu sistem; (6) jala-jala, tema/topik yang bercabang ditautkan ke dalam kurikulum, melalui tema itu warga belajar mencari konsep/gagasan yang tepat; (7) untaian simpul, pendekatan metakurikuler menjalin keterampilan berpikir, sosial, intelegensi, teknik, dan keterampilan belajar melalui variasi disiplin; (8) integrasi, pendekatan interdisipliner memasangkan antar mata pelajaran untuk saling mengisi dalam topik dan konsep dengan beberapa tim tutor dalam model integrasi riil; (9) peleburan, suatu disiplin menjadi bagian yang tak terpisahkan dari keahliannya, para pembelajar menjaring semua isi melalui keahlian dan meramu ke dalam pengalamannya; dan (10) jaringan, pembelajar menjaring semua pembelajaran melalui pandangan keahliannya dan membuat jaringan hubungan internal mengarah ke jaringan eksternal dari keahliannya yang berkaitan dengan lapangan.

Pada dasarnya, langkah-langkah pembelajaran integratif meliputi tiga tahap, yaitu perencanaan, pelaksanaan, dan evaluasi. Tahap evaluasi hendaknya memperhatikan prinsip evaluasi pembelajaran integratif, yaitu (1) menentukan jenis mata pelajaran yang dipadukan; (2) memilih kajian materi, standar kompetensi, kompetensi dasar dan indikator yang akan mengarahkan guru untuk menentukan subketerampilan dari masingmasing keterampilan dalam satu unit pelajaran; (3) menentukan subketerampilan yang dipadukan, secara umum keterampilan-keterampilan yang harus dikuasai meliputi keterampilan berpikir (thinking skill), keterampilan sosial (social skill), dan keterampilan mengorganisasi (organizing skill) yang masing-masing terdiri atas sub-sub keterampilan; (4) merumuskan indikator hasil belajar, indikator dirumuskan berdasarkan kompetensi dasar dan subketerampilan yang telah dipilih, setiap indikator dirumuskan berdasarkan kaidah penulisan yang meliputi audience, behaviour, condition, dan degree; dan (5) menentukan langkah-langkah pembelajaran, langkah ini diperlukan sebagai strategi guru untuk memadukan setiap subketerampilan yang telah dipilih pada setiap langkah pembelajaran, dalam merancang pembelajaran integratif setidaknya ada empat hal yang perlu diperhatikan, yaitu menentukan tujuan, menentukan materi/media, menyusun skenario kegiatan belajar dan pembelajaran, serta menentukan evaluasi.

Untuk menerapkan konsep pembelajaran, tutor perlu menyusun rencana pelaksanaan pembelajaran, yakni program penyajian materi pembelajaran per standar kompetensi (pokok bahasan) untuk mengarahkan kegiatan belajar warga belajar dalam upaya mencapai kompetensi dasar. Tutor berkewajiban menyusun rencana pelaksanaan pembelajaran secara lengkap dan sistematis agar pembelajaran berlangsung secara interaktif, inspiratif, menyenangkan, menantang, dan memotivasi warga belajar untuk berperan aktif serta memberikan ruang yang cukup bagi prakarsa, kreativitas, dan kemandirian sesuai dengan bakat, minat, perkembangan fisik dan psikologis, serta lingkungan warga belajar. Rencana pelaksanaan pembelajaran dapat diberikan untuk 
satu pertemuan atau lebih tergantung pada kompetensi dasar (sub pokok bahasan) yang ada. Dalam rencana pelaksanaan pembelajaran diuraikan langkah-langkah operasional pembelajaran yang dilengkapi dengan metoda, media dan evaluasi yang sesuai dengan tujuan pembelajaran. Tutor juga perlu menyiapkan bahan/media belajar dan alat peraga yang sesuai dengan materi pelajaran yang diberikan. Bahan/media belajar dan alat peraga dapat dibuat oleh tutor sendiri dengan memanfaatkan sumber daya yang tersedia atau dengan menghimpun/membelinya, atau bermitra dengan satuan pendidikan lainnya. Selain itu, tutor juga melaksanakan pembelajaran, yakni melakukan proses interaksi antara warga belajar dengan lingkungannya sehingga terjadi perubahan perilaku ke arah yang lebih baik. Proses pembelajaran perlu dilakukan dengan tenang dan menyenangkan. Hal ini menuntut aktivitas dan kreativitas tutor dalam menciptakan lingkungan belajar yang kondusif. Tutor juga melaksanakan penilaian dalam bentuk pemberian tugas, observasi, inquiri, dan bertanya langsung kepada warga belajar tentang materi yang telah disajikan. Dengan demikian tutor dapat mendeteksi bagian-bagian yang belum dipahami warga belajar dan yang kurang efektif atau sulit untuk dilaksanakan.

Salah satu kondisi pembelajaran yang dapat mendukung pencapaian kompetensi adalah mengembangkan proses pembelajaran berbasis aktivitas warga belajar dengan latar kegiatan dunia kerja. Pembelajaran yang perlu dikembangkan dalam rangka pembentukan kompetensi adalah interaksi yang memungkinkan para warga belajar mampu membangun pengetahuan, sikap, dan ketrampilannya melalui berbagai modus transformasi pengalaman belajar. Pembentukan kompetensi merupakan proses pendidikan yang memerlukan keterlibatan dari berbagai pihak terkait di luar lembaga, seperti sekolah latihan, dunia kerja/ industri, pemerintah daerah (dalam hal ini dinas pendidikan setempat, dan berbagai asosiasi profesi. Untuk itu, diperlukan terpeliharanya jaringan kerja sama/ kemitraan antara lembaga pendidikan dengan semua unsur tersebut. Kemitraan dengan dunia industri sangat diperlukan sebagai wahana pengenalan terhadap dunia kerja, standar kerja, dan perkembangan teknologi mutakhir. Jaringan kerja dengan industri atau dunia kerja perlu dikembangkan untuk membantu kelancaran dan keuntungan akademik yang optimal, sedangkan kerja sama meliputi resources sharing, problem solving, dan consortium.

Efektivitas Model Pembelajaran Terintegrasi Soft Skill dan Hard Skill untuk Meningkatkan Kompetensi Warga Belajar pada Lembaga Kursus Kecantikan

Paradigma lama sistem pendidikan bermutu yang mengacu pada sistem broad based education yang berorientasi pada peningkatan life skill masyarakat dengan mengakomodasi kebutuhan masyarakat yang dapat melanjutkan pendidikan ke jenjang pendidikan tinggi diubah ke dalam paradigma menjadi sistem focused based education yang berorientasi pada peningkatan life skill dari potensi diri dengan mengakomodasi kebutuhan dunia usaha, dunia industri, dan kewirausahaan sudah menjadi suatu kebutuhan yang dirasakan dan perlu menjadi skala prioritas untuk mengurangi pengangguran intelektual. Beberapa manfaat yang dapat dicapai adalah keluaran yang dihasilkan siap pakai, siap kerja, dan siap latih. Hal ini berarti bahwa setiap lulusan yang dihasilkan lembaga pendidikan dapat terserap dan mampu diterima oleh pasar kerja serta mampu mengaktualisasikan dirinya sendiri menjadi kreator dan inovator. Pendidikan siap pakai tersebut harus ditandai oleh penguasaan materi enterpreneur dan penggalian potensi diri yang dipadukan dengan pendidikan vokasi yang didasari kurikulum berbasis life skill. Proses pembelajaran dikatakan efektif jika seluruh warga belajar terlibat secara aktif baik mental, fisik, maupun sosialnya. Dari segi proses, pembelajaran dikatakan berkualitas jika setidaknya $75 \%$ warga belajar terlibat secara aktif dalam proses pembelajaran. Dari segi hasil, pembelajaran dikatakan berkualitas jika setidaknya $75 \%$ terjadi perubahan yang positif pada diri warga belajar.

Model pembelajaran terintegrasi soft skill dan hard skill cukup efektif untuk meningkatkan kompetensi warga belajar pada lembaga kursus kecantikan di Kota Tasikmalaya. Berdasarkan hasil uji beda menggunakan uji-t, model pembelajaran terintegrasi soft skill dan hard skill, diperoleh nilai $F$ berdasarkan hasil perhitungan SPSS sebesar 14,727 dengan tingkat signifikansi sebesar 0.000 karena probabilitas jauh di bawah 0.05. Melalui hasil tersebut, dapat disimpulkan bahwa model pembelajaran terintegrasi soft skill dan hard skill efektif untuk meningkatkan kompetensi warga belajar pada lembaga kursus kecantikan di Kota 
Tasikmalaya.

Berdasarkan pengujian menggunakan uji dua sisi dengan tingkat siginifikansi $\alpha=5 \%$ diperoleh nilai signifikansi adalah 0,000. Nilai signifikansi 0,000 lebih kecil dari 0,005 , artinya ada pengaruh penerapan model pembelajaran terintegrasi soft skill dan hard skill terhadap peningkatan kompetensi warga belajar pada lembaga kursus kecantikan di Kota Tasikmalaya. Keefektifan model ini pun dapat dilihat dari respons warga belajar terhadap penerapan pembelajaran kewirausahaan kerja sama dunia usaha dan dunia industri memenuhi kriteria sangat efektif. Tingkat keefektifan model terlihat dari respons peserta terhadap pembelajaran yang diterapkan mencakup (1) kejelasan skenario pembelajaran, (2) minat peserta kursus, (3) kesesuaian metode pembelajaran dengan usia peserta kursus, (4) kemampuan metode memotivasi peserta pelatihan untuk berwirausaha, (5) kemampuan membawa perubahan karir masa depan peserta, dan (6) penilaian umum terhadapmetode pembelajaran.

\section{PENUTUP}

\section{Kesimpulan}

Kondisi awal pembelajaran pada lembaga kursus kecantikan masih menggunakan model pembelajaran konvensional, kegiatan pembelajaran didominasi oleh tutor, sementara warga belajar sebagai pendengar setia, kurang diberikan peluang dalam memberikan tanggapan atau komentar, kurang melibatkan warga belajar dalam kegiatan pembelajaran, kurangnya kerja sama antara tutor dan warga. Model pembelajaran yang diterapkan oleh para tutor dan pamong belajar di sanggar ini belum berlandaskan konsep dan acuan yang jelas tentang model pembelajaran terintegrasi yang sesuai dengan kebutuhan nyata di lapangan yang menjadi kelompok sasaran program. Model pembelajaran masih bersifat menoton, berpusat pada tutor dan pamong belajar sementara warga belajar sifatnya menunggu dan mendengarkan materi yang disampaikan, mereka kurang dilibatkan dalam proses pembelajaran sifatnya (teacher centered).

Model pembelajaran terintegrasi merupakan suatu sistem pembelajaran yang memungkinkan warga belajar baik secara individual maupun kelompok aktif menggali dan menemukan konsep serta prinsip-prinsip keilmuan secara holistik bermakna dan otentik. Pembelajaran integratif adalah suatu proses pembelajaran dengan melibatkan berbagai bidang studi. Pendekatan pembelajaran seperti ini diharapkan akan dapat memberikan pengalaman yang bermakna kepada warga belajar. Jadi model pembelajaran integratif adalah suatu sistem pembelajaran yang memadukan bebagai macam konsep pelajaran, dalam hal ini melibatkan bebagai macam bidang studi. Pembelajaran integratif sangat penting dalam kegiatan belajar mengajar, misalnya seperti kesesuaian dunia anak yang merupakan dunia nyata, proses pemahaman anak terhadap suatu konsep dalam suatu peristiwa atau objek lebih terorganisir, pembelajaran akan lebih bermakna, memberi peluang warga belajar untuk mengembangkan kemampuan diri, memperkuat kemampuan yang diperoleh dan efisien waktu.

Implementasi model pembelajaran terintegrasi soft skill dan hard skill meliputi tiga tahap, yaitu perencanaan, pelaksanaan, dan evaluasi. Terdapat empat hal yang perlu diperhatikan dalam merancang pembelajaran integratif yaitu (1) menentukan tujuan, (2) menentukan materi/media, (3) menyusun scenario KBM, dan (4) menentukan evaluasi. Untuk menerapkan konsep pembelajaran, tutor perlu (a) menyusun rencana pelaksanaan pembelajaran, yakni program penyajian materi pembelajaran perstandar kompetensi (pokok bahasan) untuk mengarahkan kegiatan belajar warga belajar dalam upaya mencapai kompetensi dasar; (b) menyiapkan bahan/media belajar dan alat peraga yang sesuai dengan materi pelajaran yang diberikan, bahan/ media belajar dan alat peraga dapat dibuat oleh tutor sendiri dengan memanfaatkan sumber daya yang tersedia atau dengan menghimpun/membelinya, atau bermitra dengan satuan pendidikan lainnya; dan (c) melaksanakan pembelajaran, yakni melakukan proses interaksi antara warga belajar dengan lingkungannya sehingga terjadi perubahan perilaku ke arah yang lebih baik.

\section{Saran}

Beberapa saran yang diajukan berdasarkan hasil penelitian yakni sebagai berikut (1) dalam rangka pengembangan keilmuan PLS dalam proses pelayanan kebutuhan belajar sepanjang hayat dan pendidikan sepanjang hayat perlu dirancang suatu paket model pelatihan dalam upaya 
menyebarluaskan model pembelajaran integratif yang lebih aplikatif untuk peningkatan kualitas pembelajaran; (2) bagi pengelola SKB disarankan agar keberlanjutan penerapan model pembelajaran ini dapat dikembangkan sesuai dengan karakteristik warga belajar. Disarankan kepada para tutor agar dapat menerima inovasi-inovasi dalam penerapan model pembelajaran agar hasil belajar warga mengalami peningkatan; dan (3) untuk penelitian lebih lanjut dari hasil kajian teoretik tentang variabel-variabel dalam pembelajaran integratif dapat dimungkinkan untuk diteliti lebih lanjut secara mendalam dalam topik yang berbeda dan lokasi yang berbeda. Melalui penelitian lanjutan tentang pembelajaran integratif dapat dijadikan pembanding dalam mengkaji pembelajaran yang berada dalam lingkup pendidikan luar sekolah. Untuk itu terbuka dikaji secara empiris karena kehandalan dan kefektifan model pembelajaran yang dikembangkan dalam meningkatkan hasil belajar.

\section{DAFTAR PUSTAKA}

Anwar, S. (2004). Pendidikan kecakapan hidup (life skills education). Bandung: Alfabeta.

Delors, J. (1996). Learning: The treasure within, report to UNESCO of the international commision on education for the twenty-first century. Paris: UNESCO Publishing.

Depdiknas. (2007). Konsep dan strategi pengembangan pusat kegiatan belajar masyarakat (PKBM). Jakarta: Depdiknas.

Gall, M.D., Gall, J.P., \& Borg, W.R. (2003). Educational research: An introduction. New York: Ally and Bacon.

Hamalik. (1986). Proses belajar mengajar. Jakarta: PT Bumi Aksara.

Joesoef. (1986). Konsep dasar pendidikan luar sekolah. Surabaya: Bumi Aksara.

Kamil, M. (2010). Model pendidikan dan pelatihan (Konsep dan aplikasi). Bandung: Alfabeta.

Mulyasa. (2006). Kurikulum yang disempurnakan. Bandung: Remaja Rosdakarya.

Prabowo. (2000). Pembelajaran terpadu di sekolah dasar. Unesa: LPM Unesa Syah.

Rusyan, dkk. (1994). Pendekatan dalam proses belajar mengajar. Bandung: Remaja
Rosdakarya.

Saud, U.S. (2006). Perencanaan pendidikan suatu pendekatan komprehensif. Bandung: Rosdakarya.

Sihombing. (2000). Pendidikan luar sekolah, managemen strategi: Konsep, kiat dan pelaksanaan. Jakarta: PD. Mahkota.

Sudjana, N. (1987). Dasar-dasar proses belajar mengajar. Bandung: Sinar Baru Offset.

Sudjana, N. \& Ibrahim (2001). Penelitian dan penilaian pendidikan. Bandung: Sinar Baru Algesindo.

Syah, M. (1995). Psikologi pendidikan dengan pendekatan baru. Bandung: PT Remaja Rosda Karya.

Trisnahada.(2011). Pengembangan strategi penanaman nilai-nilai kejujuran dalam upaya membina disiplin dan kemandirian siswa melalui pembelajaran IPA di sekolah (studi pada MTs Negeri di Kabupaten Sumedang yang telah mengembangkan integrasi IPTEK dan IMTAQ). Disertasi. Bandung: Universitas Pendidikan Indonesia. 